\title{
Discontinuity surfaces and event stratigraphy of Okha Shell Limestone Member: Implications for Holocene sea level changes, western India
}

\author{
UdAY BhONDE ${ }^{1, *}$ and BhaWANisingh G Desai ${ }^{2, * *}$ \\ ${ }^{1}$ Pavandham Society, Samta Road, Subhanpura, Vadodara 390 023, India. \\ ${ }^{2}$ School of Petroleum Technology, Pandit Deendayal Petroleum University, \\ Gandhinagar, Gujarat, India. \\ *e-mail: uabhonde@yahoo.com \\ **e-mail: bhawanigd@gmail.com
}

The Okha Shell Limestone Member of Chaya Formation is the coarse grained, shell rich deposit commonly recognized as the beach rocks. It has been age bracketed between Late Pleistocene and Holocene. Late Quaternary sea level changes have been studied with beach rocks along the Saurashtra coastal region. The present study has been carried out in the Okhamandal area of the Saurashtra peninsula especially on the Okha Shell Limestone Member as exposed at various locations along the coast from north to south. Temporal and spatial correlations of the observations have revealed three events in the Okha Shell Limestone Member of Chaya Formation that are correlated laterally. The events show depositional breaks represented by discontinuity surfaces, the taphofacies varieties and ichnological variations. The present study in the context of available geochrnological data of the region suggests a prominent depositional break representing low sea level stand (regression) during an Early Holocene during the deposition of Okha Shell Limestone Member.

\section{Introduction}

Beach rocks are important geological features along the coast to study the sea level changes (Pirazzoli 1991). Beach rocks have been studied along the Indian coast including Andaman Islands (Wagle 1990; Merh 1992). Coastal regions of Saurashtra have good exposures of Quaternary bio-clastic deposits, categorized as calcaeranites (fine grained variety) and calcirudites (coarse and shell rich variety) (Bhatt 2003). The calcirudites or the beach rocks (Late Pleistocene to Holocene age) along the Saurashtra coast have been studied to interpret Holocene sea level changes (Gupta 1972;
Somayajulu et al 1985; Bruckner 1989; Juyal et al 1995; Bhatt and Patel 1998; Mathur and Pandey 2002; Bhonde 2004; Mathur et al 2004). Mathur (2005) suggests high sea level of 1-4 $\mathrm{m}$ during Middle and Late Holocene along the Indian coast which resulted in deposition of beach rocks along the coastline. Although good interpretations are available of sea level changes particularly of the Holocene time period based on the beach rock studies from Saurashtra; the exposure level microobservations for the beach rocks and their spatial correlations are not yet documented. The foremost aim of the present article is to demonstrate that beach rocks of the Okha Shell Limestone Member

Keywords. Beach rocks; Okha Shell Limestone Member; discontinuity surfaces; taphofacies; Early Holocene. 
of the Chaya Formation can be used to construct high resolution event stratigraphy along the coastal areas of the Okhamandal area of Saurashtra peninsula. The spatio-temporal correlation of the discontinuity surfaces, lateral variation in taphonomical facies and the ichnological details have been presented in this paper.

\section{Neogene-Quaternary geological setup of the study area}

Present study has been carried out in the Okhamandal area (figure 1), which is a part of the Saurashtra peninsula. It forms an isthmus surrounded by Arabian Sea in west and Gulf of Kachchh in the

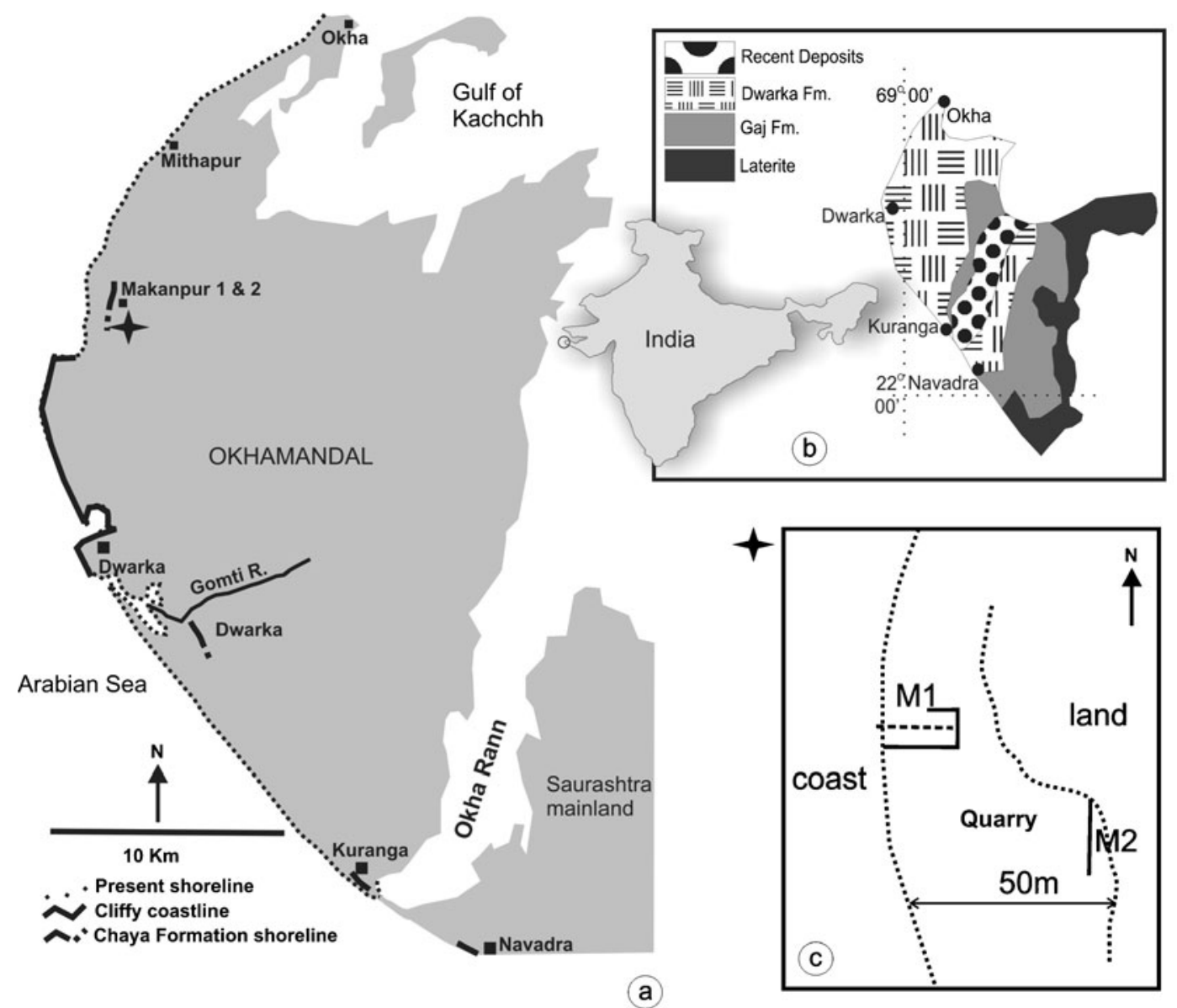

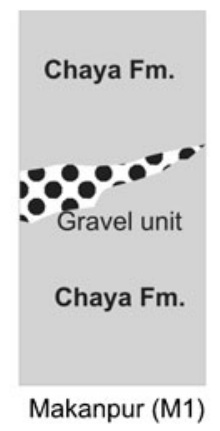

(d)

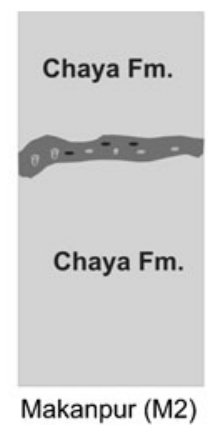

(e)

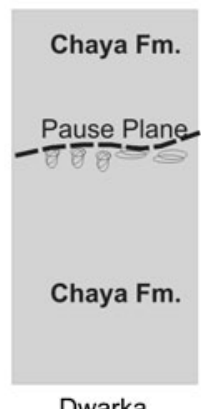

Dwarka

(f)

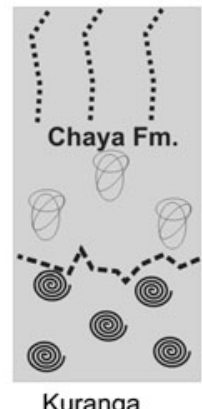

(g)

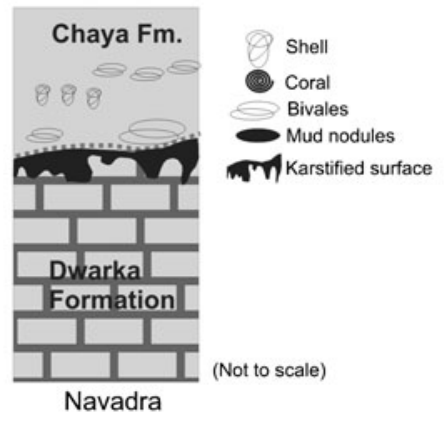

(h)

Figure 1. Details of Okhamandal study area. (a) Location map of the study area showing interpreted previous shorelines and present day shoreline. (b) Generalized geological map of the study area (after Bhatt 2000). (c) Plan of quarry section at Makanpur. (d-h) Representative logs of the different litho-sections of Okha Shell Limestone, showing discontinuity surfaces (not to scale). 
north and Okha Rann in its east (figure 1a). The Gaj, Dwarka and Chaya Formations (figure 1b) belonging to Neogene-Quaternary period are wellexposed in the Okhamandal area (Bhatt 2000). Lithologically, limestone, shale and marl of the Gaj Formation cover high topography, whereas the coastal plains are occupied with sandy facies of Dwarka Formation. Coralline and Shell Limestone of the Chaya Formation lies in the coastal stretches. Since this paper is dealing with Chaya Formation, it has been described at length. Commonly occurring along the Saurashtra coast, the Miliolite Formation of Quaternary period (Early to Late Pleistocene-Holocene) has restricted exposures in the study area. Unclassified Holocene deposits, i.e., sandy beaches, sand dunes, mud flats rests unconformably over the Pleistocene deposits (Bhatt 2003). The Shell Limestone or beach rocks in the present study area are either resting over Dwarka Formation or on the Miliolite Formation at different localities and are denoted as 'Chaya Formation' ranging in age from Late Pleistocene to Holocene (table 1).

\subsection{Chaya Formation}

Mathur and Mehra (1975) assigned the name 'Chaya Formation' to the coarse grained, bioclastic shore deposits occurring along the coastal areas of Saurashtra. The Chaya Formation is divided into two members, i.e., Okha Shell Limestone Member and Aramada Reef Member (Bhatt 2000). The Okha Shell Limestone Member is exposed all along the coastal tract of Saurashtra, whereas the Armada Reef Member is restricted only in the Okhamandal area, especially around Mithapur village (figure 1a). Thickness of the Chaya Formation is estimated to be $14 \mathrm{~m}$; of which Okha Shell Limestone Member consists of about $10 \mathrm{~m}$ (Bhatt 2000). In the outcrops, the Okha Shell Limestone Member appears as off-white, shell-hash rich often containing clasts (gravels and pebbles) of older Formations. These deposits form shore parallel linear ridges, with maximum width up to
$20 \mathrm{~m}$ and average height of $6 \mathrm{~m}$ above mean sea level (amsl). The stratification observed in them is mostly seaward dipping and the top part is duricrusted with varying intensity of karstification. Faunistically, these deposits contain unabraded invertebrate remains, dominated by bivalves and gastropods even preserved in their living positions sometimes. These coast fringing Shell Limestone deposits represent strandlines of Late Pleistocene to Holocene age (Mathur and Mehra 1975; Merh 1980).

Mathur et al (2004) presented radiocarbon dates for limited samples from the Chaya Formation, giving an age $2100 \pm 35$ yrs BP for the Turbo from Mithapur (upper part of Armada Reef Member) and $4080 \pm 90$ yrs BP for Cirithium from Porbandar (Okha Shell Limestone Member). These dated samples were collected from 2 to $5 \mathrm{~m}$ amsl and are below 6000 yrs BP. The Okha Shell Limestone Member according to Bhatt (2000) is of Middle to Late Pleistocene period. The specimens of the beach rock dated by Mathur et al (2004) are much younger than the timeframe suggested for the Okha Shell Limestone Member of the Chaya Formation.

Thus, it becomes difficult to recognize that when the word beach rock is used, whether it points to the Okha Shell Limestone Member, i.e., Chaya Formation or beach rock other than it. Therefore, the lithostratigraphic placement of beach rocks becomes important from the Middle Pleistocene onwards.

\section{Section studied from the Okhamandal area}

The Okha Shell Limestone Member (Chaya Formation) is studied in the quarry sections and at exposure level along coast in the study area. The mounds of Shell Limestone/beach rocks which are under quarrying represent an ancient beach ridge lying along the coast. Representative lithologic sections are presented in figure 1. An attempt

Table 1. Chaya Formation in the study area (after Bhatt 2000).

\begin{tabular}{|c|c|c|}
\hline Stratigraphic unit & Lithology & Age \\
\hline Holocene deposits & $\begin{array}{l}\text { Beach and dune sands, } \\
\text { tidal clays, alluvium } \\
\text {-Unconformity------------ }\end{array}$ & Holocene \\
\hline \multicolumn{3}{|l|}{ Chaya Formation } \\
\hline Armada Reef Member (4 m) & Coral Reef limestone & Late Pleistocene to Holocene \\
\hline $\begin{array}{l}\text { Okha Shell Limestone } \\
\text { Member }(10 \mathrm{~m})\end{array}$ & $\begin{array}{l}\text { Off white coloured bioclastic } \\
\text { limestone and conglomerate }\end{array}$ & Middle to Late Pleistocene \\
\hline
\end{tabular}


is made in the present study to make a stratigraphic correlation within the Okha Shell Limestone Member based on depositional breaks seen along the bounding surfaces in the quarry sections which is mostly observed in the form of gravelly horizons, differential lithification, karstified surfaces and changes in grain size in the same lithological section (figure 2a). The characteristics of the depositional breaks are recorded to interpret the temporary/long-term changes in the depositional environment setting responsible for it. Localitywise description is given for the litho-sections (in quarries or at exposure) in the following text (figure $1 \mathrm{~d}-\mathrm{h}$ ).

\subsection{Makanpur-1(M1)}

The beach ridge made up of Shell Limestone at this location is $20 \mathrm{~km}$ north of Dwarka (figure 1d). Ridge is $500 \mathrm{~m}$ away from the present day high tide line and the crest of the ridge is $6 \mathrm{~m}$ amsl. The beach ridge is oriented in the $\mathrm{N}-\mathrm{S}$ direction and quarry sections are 3 to $4 \mathrm{~m}$ (figure 1c, d). The quarry (face) section observed is perpendicular to the present day coast line. It is composed of medium to coarse grained shell limestone unit containing noticeable mega shells (gastropods and bivalves). Lateral and vertical changes in the physical parameters have been recorded here.
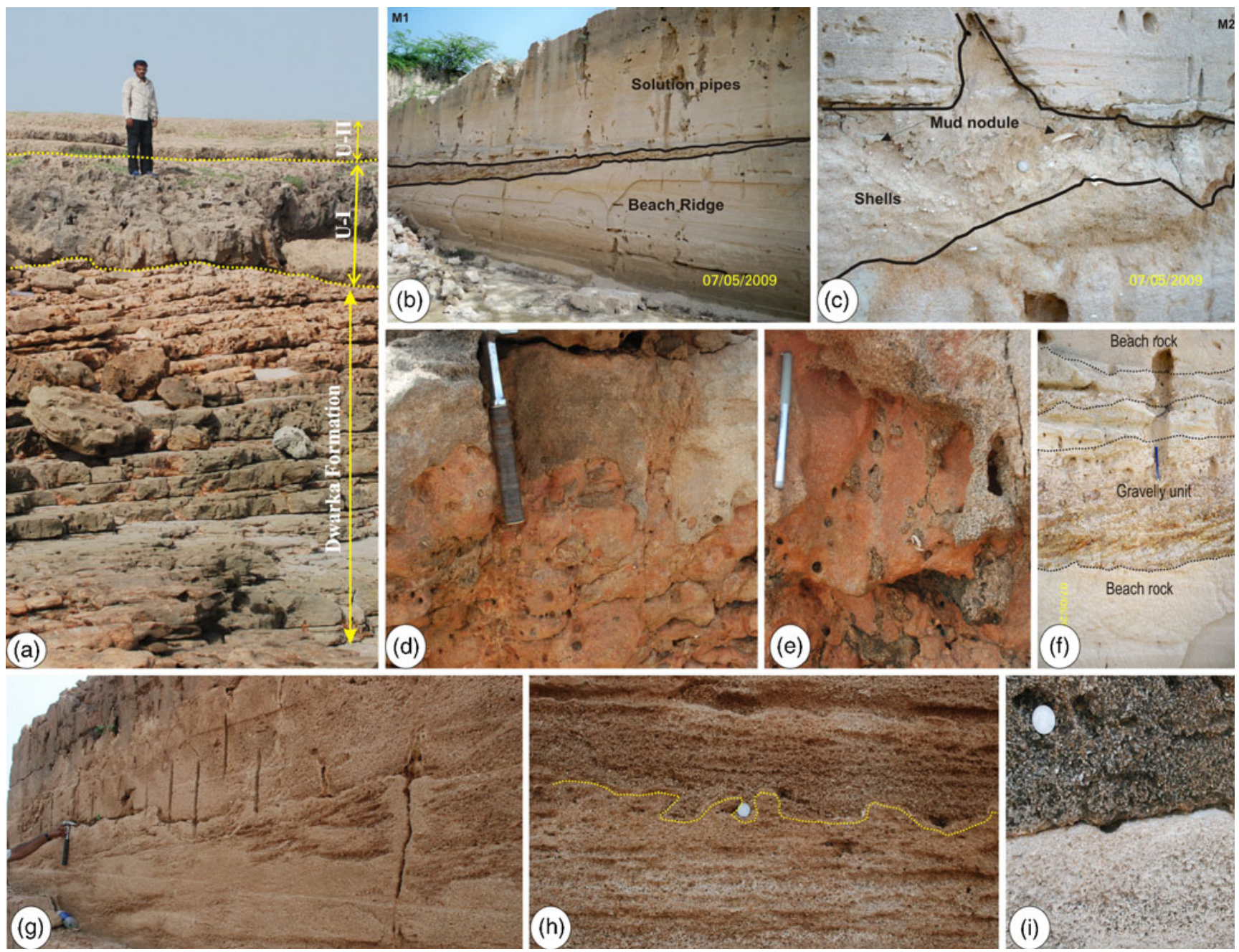

Figure 2. Mesoscale observations in Okha Shell Limestone in study area. (a) Contact between Dwarka Formation and Okha Shell Limestone at Navadra. Note the slight angular nature of the contact (height of person $160 \mathrm{~cm}$ ). (b) Lensoidal gravelly layer of Unit 2 in Makanpur section (M1). The thickness is increasing towards present day shoreline. (c) In situ bivalves and polychaete tubes in mudy silt bed, with the occurrence of mud nodules at Makanpur section (M2). (d) Intensely karstified Dwarka Formation, filled by Okha Shell Limestone (Navadra) (Hammer: $30 \mathrm{~cm}$ ). (e) Karstified surfaces comprising of open spiral burrow system filled by Okha Shell Limesone at Navadra (scale: $2 \mathrm{~cm}$ ). (f) Close-up view of gravel unit at Makanpur (M1), note fining upward sequence and sharp erosional contact with below lying sediments. (g) Karstified discontinuity surface extending in quarry section at Dwarka, indicating lithification and subsequent karstification of underlying sediments. (h) Irregular nature of karstified discontinuity surface at Dwarka (coin diameter: $2.4 \mathrm{~cm}$ ). (i) Omission surface as indicated by lithified shell lense, showing sharp break in Okha Shell Limestone. 
A prominent break in the form of lensoidal gravelly horizon is observed in the section (figure $2 \mathrm{~b}$ ) which pinches out towards the land. The gravel horizon attains maximum thickness of about $40 \mathrm{~cm}$ in central part, and oriented towards the present day coast (figure 2f). In general, gravelly horizon represents fining upward sequence. It exhibit trough cross-bedding type of sedimentary structure in which the cross-strata are of solitary, small scale in nature having curved and sharp lower bounding surface. The individual cross strata are low angled, concave shaped. The clasts observed in the gravelly horizon range in size from $5-10 \mathrm{~cm}$ and are rounded to sub-rounded in nature. These clasts seem to be derived from the shore platforms. The semifossilized, well preserved shells of adult bivalves and gastropods have also been found. Mostly they are scattered but also observed in cluster of varying size.
The Okha Shell Limestone in the Makanpur (M1) section represents three differentiable units: lower unit (Unit 1) as base, gravelly unit (Unit 2a) and upper unit (Unit 3).

\subsection{Makanpur-2 (M2)}

This section is parallel to coastline and is located about 50 to $70 \mathrm{~m} \mathrm{SE}$ of the previously described section (M1) in the same quarry (figure 1c). Though lying in the vicinity of M1, M2 section shows significant facies variation. In contrast to the lensoidal gravelly horizon observed in M1 here; thin, laterally extensive unit of fine grained sediments is present. The unit is extending along the strike, i.e., $\mathrm{N}-\mathrm{S}$ and is parallel to the coastline. The $60 \mathrm{~cm}$ thick unit in mid-part of the section is composed of silty-to-clayey sediments. It
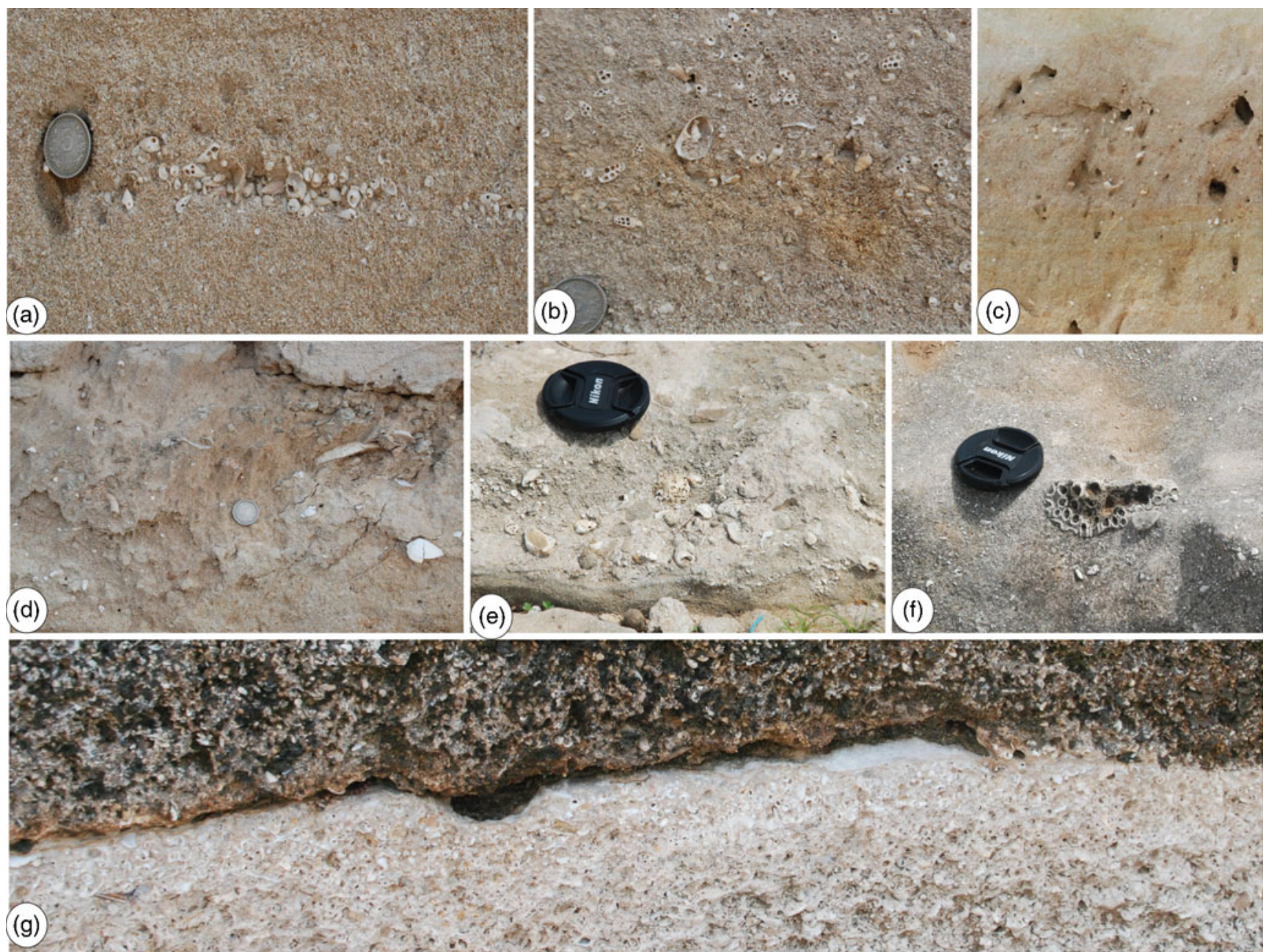

Figure 3. Taphofacies observed in Okha Shell Limestone. (a) Gastropod lense facies at Makanpur (M2), note the closely packed gastropods. (b) Dispersed matrix supported taphofacies at Makanpur (M1). (c) Nature of low diversity, dispersed matrix supported gastropod shells at Makanpur (M2). (d) Gastropod bivalve loosely packed facies at Makanpur (M2), note the unabraded nature of fossils. (e) Poorly sorted coral gastropod facies at Kuranga. (f) Solitary coral in poorly sorted coral-gastropod facies at Kuranga. (g) Gastropod lens overlain by omission surface. 
contains semi-fossilized shells of gastropods, calcareous polychaete tubes and broken, unabraded, poorly sorted bivalve shell fragments (figures 1e and 2c). The upper $10 \mathrm{~cm}$ of the unit is made up of grit to pebble sized grey coloured mud nodules.

The section comprises of three units: lower unit (Unit 1), silty-clay unit (Unit 2b) and upper unit (Unit 3).

\subsection{Dwarka}

The section is exposed in a quarry located south of Dwarka (figure 1a). It is about 3 to $4 \mathrm{~m}$ amsl and represents typical Chaya Formation, coarse grained shell limestone. Here, two compositionally similar units are separated by a distinct pause plane. The pause plane separating two units is represented by various types of discontinuity surfaces (figure $2 \mathrm{~g}$, h) and can be traced in entire quarry area. The lower unit in the section is capped by $10-15 \mathrm{~mm}$ thick, laterally extended, dense accumulation of partially broken, unabraded small sized gastropod shells (figures $2 \mathrm{i}$ and $3 \mathrm{~g}$ ). The physical sedimentary structure observed are crudely laminated massive and convolute beds, the biogenic structures are also visible in the sections at this locality.

The section in locality comprises of two units: lower unit (Unit 1) and upper unit (Unit 3) of similar nature. Unit 2 is represented by a discontinuity surface/pause plane indicating a break in the deposition.

\subsection{Kuranga}

Kuranga is located $20 \mathrm{~km}$ south of Dwarka (figure 1a) and section is in the form of rocky exposures. It is exposed at about $1-2 \mathrm{~m}$ amsl and is just $50 \mathrm{~m}$ away from the present high tide level. This is the nearest section from the coast when compared with earlier section. At the base of this section abundant coral fragments and diverse assemblage of gastropod and bivalve shells are seen (figures $1 \mathrm{~g}, 3 \mathrm{f}$ ). However, the top part of the exposure is poor in shell concentration (gastropod, bivalve shells and coral fragments) showing high degree of digenesis represented by compact nature or rock. This is not observed at other section in the study area. The upper surface shows orthogonal joints. The unit abuts against an $\mathrm{E}-\mathrm{W}$ oriented ridge composed of the Neogene sediments perpendicular to coast. The section comprises of two units: lower unit, abundant in coral clasts (Unit 1); upper unit (Unit 3). Unit 2 is represented by a karstified and discontinuity surface.

\subsection{Navadra}

Thickest exposure of Okha Shell Limestone Member of the Chaya Formation is seen at Navadra (figure 1a), the southernmost section in the study area. It is resting over older limestones of Dwarka Formation (figures $1 \mathrm{~h}$ and $2 \mathrm{a}$ ). The coast is cliffy in nature formed of Okha Shell Limestone Member. Contact between older unit of Dwarka Formation and the Chaya Formation is karstified surface. The sediments are filled in karstified surface. In contrast to previously described sections here, Okha Shell Limestone hardly possess complete shells. Otherwise, mostly the unit is homogenous in nature comprised of abraded shell fragments.

The section comprises of two units: lower unit rich in fossil fragments (Unit 1); upper unit (Unit 3). Unit 2 is represented by a karstified and discontinuity surface. Karstified surface is also present under Unit 1 (figure 1h).

\section{Results}

\subsection{Taphofacies}

Taphofacies are sedimentary rock units characterized by the combination of preservational features of the fossils contained within it. The taphonomic signature of the rocks reflects the depositional environment and is also likely to preserve signatures of paleoenvironmental and hydrodynamic conditions prevailed during the deposition of the rock (Kidwell 1991).

In the present study, the taphonomic facies of the Chaya Formation were delineated based on methods given by Kidwell (1991). The method involves various attributes like: (1) shell abundance, (2) packing (percentage of fossils per rock volume), (3) fragmentation, (4) articulation, (5) left/right valve proportion, (6) bio-fabric (original growth position, the lowest angle of the shells to the stratification surface and the concavity orientation), (7) preservation of the original mineralogy, (8) edge rounding, and (9) biological interactions. The bioclasts packing and the percentage of bio-clasts per rock volume were estimated following Kidwell and Holland (1991).

In general four taphofacies, (1) gastropod lens facies (GLF), (2) dispersed matrix supported facies (DMSF), (3) gastropod-bivalve loosely packed facies (GBLPF), and (4) poorly sorted coralgastropod facies (PSCGF), are recognized from two distinct units (Units 1 and 3) of Chaya Formation which also shows lateral facies variation. The sediments are bio-clastic in nature, medium to well sorted, with the grain size ranging between silt to sand.

\subsubsection{Gastropod lens facies (GLF) (Plate 3a and g)}

This facies is the most common facies and occurs dominantly in Makanpur and Dwarka quarry 
sections described earlier. This facies contains concentration of few species of gastropod, viz., Diloma sp., Jujubinus sp., turritella, natica sp., etc., all of them are mostly adult shells and represents benthic habitat. Taphonomically, these are well preserved, with little abrasion and are unfragmented. They occur as densely packed, well sorted shell concentration with well preserved ornamentation surface. This fossil accumulation occurs as lens geometry.

Similar concentrations have been interpreted as hydraulic shell lags and were also studied from deeper environment by Norris (1986) and Clifton (1989). Cohen (1989), studied small clumps of gastropods in varied state of preservation from a freshwater lake and interpreted them as winnowing by fishes for nesting as a primary cause of concentration. Based on the nature of occurrence, preserved taphonomic features and geometry of the concentration in the present section, it can be interpreted that this gastropod shell concentration are intrinsic to locally inhabiting gastropods community and their post mortem concentration is result of hydraulic reworking during high energy conditions in intertidal/subtidal zone.

\subsubsection{Dispersed matrix supported facies (DMSF)} (Plate $3 b$ and $c$ )

The facies commonly occurs in Makanpur, Dwarka sections. It comprises of low diversity of gastropod species and dominantly comprising of mixed age spectrum fauna. Taphonomically well preserved, unabraded, unfragmented gastropod shells are seen. The shells are loosely packed (15\%), dispersed, matrix supported with sparsely distributed, poorly sorted bio-clasts. The shell concentration is well preserved and fossils are of mix age spectrum. Based on preservation of shell concentration, it can be interpreted that these fossils have formed in low energy conditions. Similar type of dispersed matrix supported shell concentrations were also observed in recent lagoon along the Mandvi coast, Kachchh, Gujarat (Patel and Desai 2009).

\subsubsection{Gastropod-bivalve loosely packed facies (GBLPF) (Plate 3d)}

This facies occurs in all sections of the present study area. The gastropod and bivalve species diversity is low but comprise of mix age spectrum fauna. Taphonomically, $40 \%$ of the bivalve shells are disarticulated but closely associated with moderate sorting. The disarticulated shells also show preferred orientation of convex-up nature in cross section. Although some of the bivalves are preserved in their life position and are articulated. The ornamentations of gastropod shells are abraded but some are preserved as broken fragments of well sorted nature. Another important element in this facies is the association of calcerous polychaete tubes in their growth position. Similar polychaete tubes were also reported from Mundra tidal flats (Patel and Desai 1998) and Mandvi intertidal zone (Patel and Desai 2009). Based on the types of disarticulation of shells and preserved orientation of bivalves and gastropods, a winnowing action along with low rate of sedimentation and delayed burial is envisaged for this facies. Such types of conditions are common in low energy environment. Hence, a low energy condition is interpreted for the present facies.

\subsubsection{Poorly sorted coral-gastropod facies (PSCGF) (Plate 3e, f)}

The facies is well represented in the Kuranga section and it comprises of pebble shaped rolled-up coral heads which are angular in nature, but lack subsequent biological modifications, i.e., biological borings or encrustations. However, the gastropods are fragmented as well as abraded having rounded edges. This suggests that the gastropods might be result of reworked gastropods from the earlier shell beds. This mixed type of fossil concentrations is interpreted to have formed in high energy conditions.

The taphofacies from the present study are summarized in table 2. The units described therein are stratigraphically arranged from older to younger.

Unit 1: Although it is massive, it comprises of lenses of shell concentrations. Taphonomically, the shell concentrations of the Unit 1 comprise of monotypic taxonomic composition of shells, which are of mix age spectrum. Packing is matrix supported and geometry of the shell accumulations occurs as stringer, lens and pod. The bivalve shells are disarticulated and closely associated with moderate to well sorted sediments. Lateral facies variation is observed in study area and is represented by gastropod lens facies at Makanpur changing to coral-gastropod facies at Kuranga and Nawadra. The lower boundary is sharp and erosional base lying over karstified Dwarka Formation. The top boundary of the Unit 1 shows erosional nature at Makanpur, karstified topography at Kuranga, and hard ground at Dwarka section (figures $1 \mathrm{~d}-\mathrm{h}$ and 2).

The overlying Unit 2 is only observed at Makanpur section which comprises of imbricated, cross bedded gravels with erosional base in the area towards the sea. Towards the land, this is replaced by burrowed fine silty-muddy sediments with abundant gastropods, corals, bivalves, polychaete tubes, 
Table 2. Summary of taphofacies in the study area (Unit 1=1; Unit 2=2 and Unit 3=3).

\begin{tabular}{llccc}
\hline \multirow{2}{*}{$\begin{array}{l}\text { Section } \\
\text { (north to south) }\end{array}$} & GLF & DMSF & GBLPF & PSCGF \\
\cline { 2 - 5 } Makanpur (M1) & 1 & & 2 & \\
Makanpur (M2) & 1,3 & 2 & 2 & \\
Dwarka & 1,3 & 2 & & \\
Kuranga & 1,3 & & & 1 \\
Navadra & 1,3 & & & 1 \\
\hline
\end{tabular}

etc. The gravelly unit is thickened towards the seaward side and thinned towards the landward side.

Unit 3 is younger and is observed at all sections of the study area. It rests over karstified surface at Kuranga and on hard ground surface at Dwarka and on Unit 2 at Makanpur.

Three distinct units are recognized in all the sections in present study area. Figure $1(\mathrm{~d}-\mathrm{h})$ represents all sections of the study area, i.e., Makanpur, Dwarka, Kuranga and Navadra.

\subsection{Discontinuity surfaces}

Depositional breaks in sedimentation process are easily recognized, if preserved as discontinuity surfaces in the outcrop or litho-section. Thus, they form an integral part of the stratigraphic record and help in further analysis of sedimentation history. According to Hillgartner (1998), small-scale and short-lived discontinuities may also reflect large scale variations of relative sea level.
In present study area, Unit 1 and Unit 3 are separated by a strong discontinuity surface. This discontinuity surface is not of uniform nature along the coastal stretch in the present study area, but can be differentiated into five genetic types of discontinuities. These discontinuities are classified based on (1) geometry, (2) surface and sectional morphology, (3) lateral extent, and (4) biological activity. In the present study, the discontinuity surfaces are classified as per the scheme of Hillgartner (1998) and interpretations are followed by referring to it. The types of discontinuity observed at various litho-sections (quarry or rock exposure) are summarized in table 3 .

\subsection{Ichnology}

Ichnologically, the Okha Shell Limestone Member belong to Skolithos ichnofacies and six distinct traces have been recognized, viz., Rosselia socialis, Skolithos linearis, S. verticalis, S. isp, Planolites, and Conichnus conicus (figure 4).

Table 3. Summary of the discontinuity surfaces observed in the Okha Shell Limestone Member in the present study area.

\begin{tabular}{|c|c|c|c|c|}
\hline Site & Geometry & Morphology & $\begin{array}{l}\text { Stratigraphic } \\
\text { placement }\end{array}$ & Interpretation \\
\hline $\begin{array}{l}\text { Makanpur (M1) } \\
\text { Perpendicular } \\
\text { to shore }\end{array}$ & $\begin{array}{l}\text { Mainly } \\
\text { depositional }\end{array}$ & Erosional breaks & Top of Unit 1 & $\begin{array}{l}\text { Simple discontinuity } \\
\text { surface in subintertidal } \\
\text { environment }\end{array}$ \\
\hline $\begin{array}{l}\text { Makanpur (M2) } \\
\text { Parallel to shore }\end{array}$ & Depositional, flat & $\begin{array}{l}\text { Strongly } \\
\text { bio-turbated }\end{array}$ & $\begin{array}{l}\text { Top of Unit } 1 \text { and } \\
\text { Unit } 2\end{array}$ & $\begin{array}{l}\text { Simple discontinuity } \\
\text { surface in subintertidal } \\
\text { environment }\end{array}$ \\
\hline Dwarka & $\begin{array}{l}\text { Simple, } \\
\text { hard ground, } \\
\text { erosional surface }\end{array}$ & $\begin{array}{l}\text { Irregular, } \\
\text { undulating }\end{array}$ & Top of Unit 1 & $\begin{array}{l}\text { Erosional surface } \\
\text { in subintertidal } \\
\text { environment }\end{array}$ \\
\hline Kuranga & $\begin{array}{c}\text { Karstified surface, } \\
\text { erosional nature }\end{array}$ & $\begin{array}{l}\text { Undulating, jagged, } \\
\text { pitted, etched } \\
\text { cavities }\end{array}$ & Top of Unit 1 & $\begin{array}{c}\text { Microkarst, Epikarst } \\
\text { subaerial exposure }\end{array}$ \\
\hline Navadra & $\begin{array}{l}\text { Strongly karstified: } \\
\text { surface, cavities } \\
\text { filled with overlying } \\
\text { sediments }\end{array}$ & $\begin{array}{l}\text { Strongly } \\
\text { undulating, jagged, } \\
\text { pitted, etched } \\
\text { cavities }\end{array}$ & $\begin{array}{l}\text { Top of Dwarka } \\
\text { Formation/Base } \\
\text { of Unit } 1\end{array}$ & $\begin{array}{l}\text { Karstified, subaerial } \\
\text { exposure for longer } \\
\text { duration }\end{array}$ \\
\hline
\end{tabular}



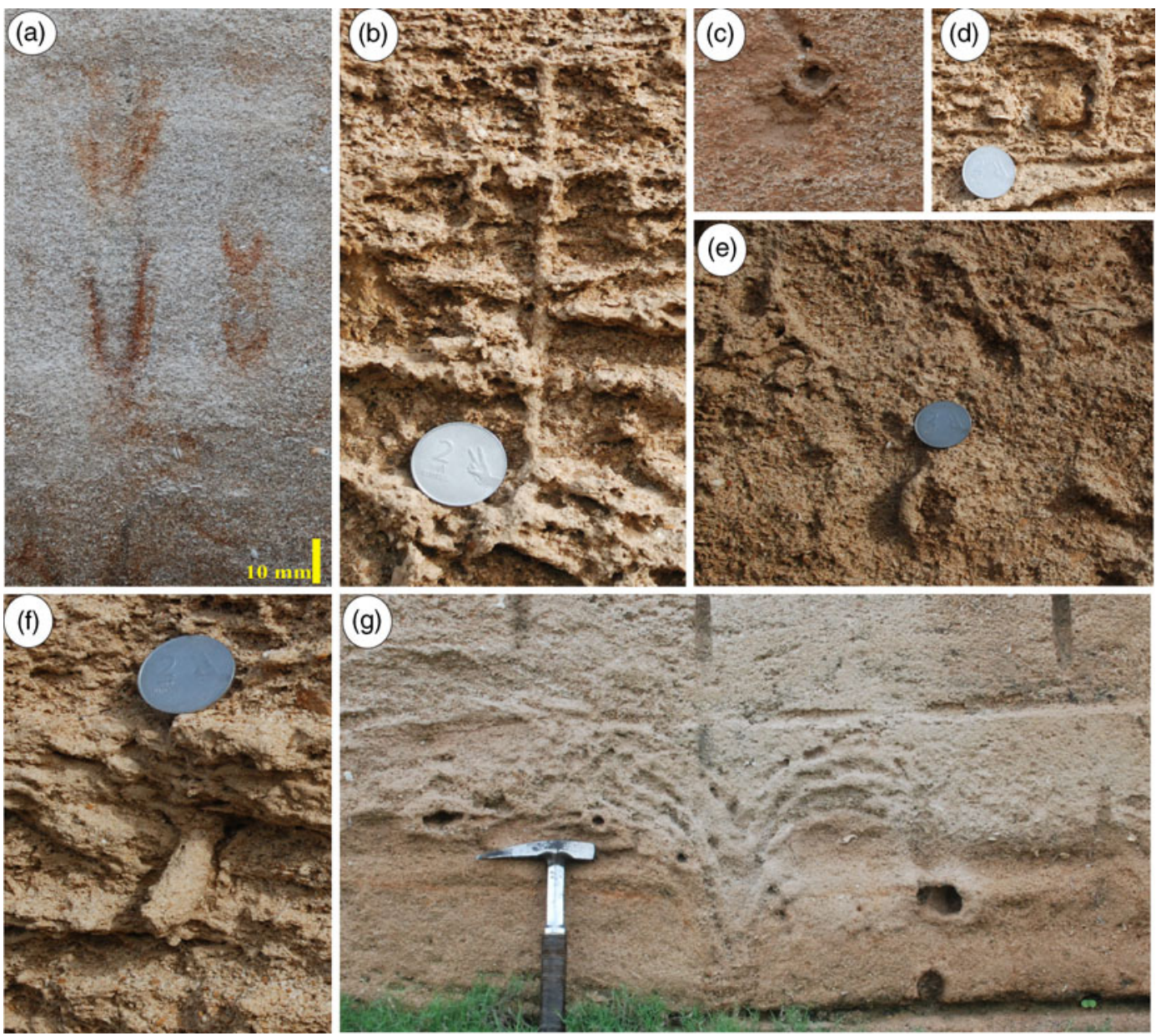

Figure 4. Trace fossils of Okha Shell Limestone (coin diameter: $2.4 \mathrm{~cm}$ ). (a) Vertically stacked, re-equilibrated Rosselia socialis at Dwarka. (b) Skolithos linearis at Makanpur section. (c) Skolithos verticalis in Dwarka section. Note the thick lining of wall. (d) Short burrow of Skolithos isp. (e and f) Horizontal feeding burrow of Planolites isp at Dwarka. (g) Conichnus conicus - a large conical escape structure in lower unit at Dwarka.

\subsubsection{Rosselia socialis (figure 4a)}

They occur as cylindrical, vertically stacked, re-equilibrated, with opening expanded and filled with concentric layer of matrix. Rosselia is a common ichnogenus associated with the Skolithos ichnofacies in storm dominated successions (MacEachern et al 2007) and are common fossils of shallow marine deposits (Nara 1997; Frieling 2007). Such traces are interpreted to be made by organism for dwelling and feeding purpose (Schlirf 2003). It occurs in Unit 1 of Makanpur quarry section.

\subsubsection{Skolithos linearis (figure 4b)}

This is dominant trace fossil of Unit 1 with an unlined and simple burrow. It is un-branched up to $200 \mathrm{~mm}$ in length with diameter ranging from 3 to $5 \mathrm{~mm}$. The burrow fill is massive. These trace fossils are common in Makanpur as well as Dwarka sections.

\subsubsection{Skolithos verticalis (figure 4c)}

This trace fossil differs from the other Skolithos species in having thick lining. The diameter is between 18 and $24 \mathrm{~mm}$ with lining up to $6 \mathrm{~mm}$ thick. The trace fossils are common in Dwarka and Makanpur sections.

\subsubsection{Skolithos isp (figure 4d)}

This trace fossil differs from other Skolithos by having unlined nature with coarse grained infilling materials. These trace fossils are common in Makanpur as well as Dwarka sections.

\subsubsection{Planolites isp (figure 4e $\& f$ )}

The trace fossils occur in Unit 1 association with Conichnus at Dwarka section. It is cylindrical-toelliptical, unlined and horizontally oriented tube. 


\subsubsection{Conichnus conicus (figure 4g)}

The trace fossils occur in Unit 1 at Dwarka section. It is conical, sub-cylindrical trace oriented perpendicular to the bedding with rounded base and internal filling associated escape/collapse structure. Conichnus conicus is generally attributed to the escape-burrowing activities of sea anemones (Shinn 1968; Curran 2007).

Laterally two distinct ichnological associations are found in Unit 1. (1) Conichnus-Planolites ichnoassociation exposed at Dwarka section and (2) Rosselia ichno-association exposed at Makanpur section. Conichnus-Planolites ichno-association is well exposed in the quarries near Dwarka. Other common trace fossil of this association includes Skolithos linearis and S. isp. The Bioturbation index (BI) is between 1 and 2. Curran (2007), interpreted Conichnus-Planolites ichno-association as a part of Skolithos ichnofacies and considered it to be shallow subtidal ichnocoenosis. Occurrence of Conichnus has also been reported from carbonate sand substrates, especially cross bedded grainstone deposited in shallow subtidal environment (Shinn 1968; Halley and Evans 1983; Pemberton and Jones 1988; Curran and White 1997; Curran 2007). Hence, Unit 1 of the Dwarka section is considered to be deposited in a shallow subtidal environment with high energy conditions. On the contrary, the Makanpur section, which have ichno-association Rosselia comprises of Rosselia socialis along with Skolithos verticalis. The BI of Unit 1 exposed at this location is 2 . R. socialis are indicative of inter to subtidal environment (Nara 1997; Uchman and Krenmayr 1995; Frieling 2007; MacEachern et al 2007).

Overall, the occurrence of the trace fossils strongly indicates relatively strong wave or current energy in relatively clean, well-sorted, shifting particulate substrates. Such substrates usually undergo abrupt changes in rates of deposition, erosion, and physical reworking of sediments (Pemberton et al 2001; MacEachern et al 2007).

\section{Discussions and summary}

The Okha Shell Limestone Member of the Chaya Formation is made up of coarse grained bioclastic sediments. Three events are recognized in it and taphofacies variation, discontinuity surfaces and ichnological association of them are studied. Characteristics observed in these units indicate that fluctuation in the sea levels is responsible for their formation during their deposition (Early Holocene).

Three units are recognized of which, the lower unit (Unit 1) shows distinct lateral facies variation.
This unit overlies the intensity karstified Dwarka Formation and hence is stratigraphically considered oldest unit from the three units recognized. Ichnologically it is characterized by ConichnusPlanolites ichno-association as well as Rosellia ichno-association, indicating subtidal/intertidal conditions with high energy. Taphonomically, also the dominance of gastropod lens facies (GLF) and poorly sorted coral gastropod facies (PSCGF) observed which are indicative of high energy marine conditions that also experiences hydraulic reworking.

All along the Saurashtra coast (except Okhamandal) mostly the Dwarka Formation (Middle Miocene to Pliocene) is conformably overlain by Miliolite Formation (Early to Middle Pleistocene) which is again overlain by Chaya Formation (Late Pleistocene to Holocene). However, in the present study area, i.e., the Okhamandal, mostly the Dwarka Formation is unconformably overlain by Chaya Formation (Unit 1). This unconformity represents nondeposition of Miliolite Formation in the study area and is represented by strongly karstified upper surface of Dwarka Formation, indicating subaerial exposure for longer duration which should be usually during regression or drop in sea level. Hence (Unit 1) indicating subtidal/intertidal environment overlying a subaerially exposed karstified surface is interpreted to be a transgressive deposit.

Unit 2 is represented by an unconformity and its lateral conformity. The lateral conformity is represented by the subunits (2a) the cross stratified gravel wedge and $(2 \mathrm{~b})$ silty clay unit. The taphofacies observed in the subunit indicates its deposition in lagoonal environment. The unconformity is represented by variety of discontinuity in the form of karstified surface. Moreover, such karstified surfaces are interpreted to be generated when sea level falls or regression occurs.

Unit 3 rests over Unit 2 in all the litho-sections observed in the present study area. The taphofacies and ichnological assemblages of the Unit 3 indicate intertidal depositional environment with higher energy conditions. It is envisaged for this unit that it represents a transgressive event. This unit might correspond to Middle Holocene high sea level, i.e., 6000 yrs BP (Gupta 1972; Somayajulu et al 1985; Mathur 2005).

Mathur (2005) reviewed the available dates of the Chaya Formation and categorized them in two groups (1) Late Pleistocene (176-61 ky) and (2) Middle Holocene (6 ky). Based on these dates Mathur (2005) suggests age of the Chaya Formation to be Late Pleistocene to Middle Holocene.

The observations made during this study and the available published dates of the Chaya Formation indicate that the period involved in the formation 
of the discontinuity/unconformity represented by Unit 2 of the Okha Shell Limestone Member in the study area should be Early Holocene (10-7 ky BP). The discontinuity in the form of Unit 2 thus also represents a regressive phase of the sea level in the study area for that time period.

Following points summarizes the study.

- The Okha Shell Limestone Member can be further divided into subgroups (i.e., three units, Unit 1; Unit 2 and Unit 3) in present study representing transgressive-regressive-transgressive events.

- Four taphofacies are identifiable in Okha Shell Limestone Member.

- Four types of genetically distinct discontinuity surfaces are identifiable.

- Six recurring ichnospecies are identified and can be grouped in two ichno-association (1) Conichnus-Planolite and (2) Rosallia.

- In the light of already published geochronological details and their correlation with present stratigraphic correlation, a break at during Early Holocene (7000 yr BP) is delineated during the Okha Shell Limestone Member representing the low sea level stand.

- With further studies, at least in present area, it is possible to comment on pattern of sea level change/sequence or reasons of fall of the sea level.

\section{References}

Bhatt N 2000 Lithostratigraphy of the NeogeneQuaternary deposits of Dwarka-Okha area, Gujarat; J. Geol. Soc. India 55 139-148.

Bhatt N 2003 The Late Quaternary bioclastic carbonate deposits of Saurashtra and Kachchh, Gujarat, Western India: A Review; Proc. Indian Natl. Sci. Acad. 69 137-150.

Bhatt N and Patel M P 1998 Bioclastic shore deposits: Indicators of late Quaternary high sea in Saurashtra, western India; J. Geol. Soc. India 52 537-542.

Bhonde U 2004 Late Quaternary Geomorphic Evolution of the Southwestern Saurashtra Coast, Gujarat, Western India (Unpubl. Ph.D. Thesis), Department of Geology, The Maharaja Sayajirao University of Baroda, Vadodara, p. 190.

Bruckner H 1989 Late Quaternary shorelines in India; In: Late Quaternary Sea-Level Correlation and Applications (eds) Scott D B P, Pirrazzoli P A and Honig C A, Dordrecht, pp. 169-194.

Clifton H E 1989 Sedimentologic approaches to paleobathymetry with applications to the Merced Formation of central California; Palaios 3 507-522.

Cohen A S 1989 The taphonomy of gastropod shell accumulations in large lakes: An example from Lake Tanganyika, Africa; Paleobiology 15 26-45.

Curran H A 2007 Ichnofacies, ichnocoenoses, and ichnofabrics of Quaternary shallow-marine to dunal tropical carbonates: A model and implications; In: Trace fossils: Concepts, problems and applications, pp. 52-77.
Curran H A and White B 1997 A Conichnus conicusgenerated ichnofabric in late Pleistocene limestones at Clifton Pier, New Providence Island, Bahamas; In: Guide to Bahamian Ichnology: Pleistocene, Holocene, and Modern Environments: San Salvador, Bahamian Field Station, Bahamas (ed.) Curran H A, pp. 55-61.

Frieling D 2007 Rosselia socialis in the Upper Marine Molasse of southwestern Germany; Facies $\mathbf{5 3}$ 479492.

Gupta S K 1972 Chronology of the raised beaches and inland coral reefs of the Saurashtra coast; J. Geol. 80 357-361.

Halley R B and Evans C C 1983 The Miami limestone: A guide to selected outcrops and their interpretation; Miami Geological Society, p. 67.

Hashmi N H N, Nair R R and Rajagopalan G 1995 Holocene sea level fluctuation on western Indian continental margin: An update; J. Geol. Soc. India 44 685-689.

Hillgartner H 1998 Discontinuity surfaces on a shallowmarine carbonate platform (Berriasian, Valanginian, France and Switzerland); J. Sedimentary Res., Section B: Stratigraphy and Global Studies 68 1093-1108.

Juyal N, Pant R K, Bhushan R and Somayajulu B L K 1995 Radiometric dating of late Quaternary sea levels of the Saurashtra coast, western India: An experiment with oyster and clam shells; Quaternary Environments 83 Geoarchaeology of India, Essays in honour of Prof. S. N. Rajaguru 32 372-379.

Kidwell S M 1991 The Stratigraphy of shell concentrations; In: Taphonomy: Releasing the data locked in the Fossil record (eds) Allison P A and Briggs D E G (New York: Plenum Press), pp. 211-290.

Kidwell S M and Holland S M 1991 Field description of coarse bioclastic fabrics; Palaios 6 426-434.

MacEachern J A, Pemberton S G, Gingras M K and Bann K L 2007 The ichnofacies paradigm: A fifty years retrospective; In: Trace Fossils: Concepts, Problems and Applications (ed.) Miller W III (Amsterdam: Elsevier), pp. $52-77$.

Mathur U B 2005 Quaternary geology: Indian perspective (with notes on Quaternary of Gujarat); Geological Society of India, Bangalore.

Mathur U B and Mehra S 1975 Quaternary deposits of Porbandar area, Junagarh District, Gujarat; Unpubl. report, Geological Survey of India.

Mathur U B and Pandey D K 2002 Radiocarbon dates of corals, gastropods and foraminifers from Saurashtra peninsula, Gujarat and their implications for sea level studies; J. Geol. Soc. India 60 303-308.

Mathur U B, Pandey D K and Bahadur T 2004 Falling Late Holocene sea level along the India coast; Curr. Sci. 87 439-440.

Merh S S 1980 The Miliolite problem: Presidential address to the Geology and Geography Section, Indian Science Congress, 67th session, Kolkata.

Merh S S 1992 Quaternary sea level changes along Indian Coast; Proc. Indian Natl. Sci. Acad. 58 461-472.

Nara M 1997 High resolution analytical method for event sedimentation using Rosselia socialis; Palaios 12 489-494.

Norris R D 1986 Taphonomic gradients in shelf fossil assemblages: Pliocene Purisima Formation, California; Palaios $1256-270$.

Patel S J and Desai B G 1998 Animal-sediment relationship in a modern tidal flat environment on Mundra coast, Gulf of Kachchh, Gujarat; Quaternary of India Special Issue 4 315-320.

Patel S J and Desai B G 2009 Animal-sediment relationship of the crustaceans and polychaetes in the intertidal zone 
around Mandvi, Gulf of Kachchh, western India; J. Geol. Soc. India $\mathbf{7 4 ( 2 )} 233-259$.

Pemberton S G and Jones B 1988 Ichnology of the Pleistocene Ironshore Formation, Grand Cayman Island, British West Indies; J. Paleontol. 62 495-505.

Pemberton S G, Spila M, Pulham A J, Saunders T, MacEachern J A, Robbins D and Sinclair I K 2001 Ichnology and sedimentology of shallow to marginal marine systems: Ben Nevis and Avalon Reservoirs, Jeanne d'Arc Basin; Short Course Notes V. 15, Geological Association of Canada, St. John's, Newfoundland, p. 343.

Pirazzoli P A 1991 World Atlas of Holocene Sea Level Changes; Elsevier, Amsterdam.
Shinn E A 1968 Burrowing in recent lime sediments of Florida and the Bahamas; J. Paleontol. 42 879-894.

Schlirf M 2003 The palaeoecologic significance of Late Jurassic Trace Fossils from the Boulonnais. N France; Acta Geologica Polonica 53 123-142.

Somayajulu B L K, Broecker W S and Goddard J 1985 Dating Indian corals by U Decay Series Method; Quat. Res. 24 235-239.

Uchman A and Krenmayr H G 1995 Trace fossils from lower Miocene (Ottnangian) mollasse deposits of upper Austria; Paläontologische Zeitschrift 69 503-524.

Wagle B G 1990 Beach rocks of the central west coast of India; Geo-Marine Letters 10 111-115.

MS received 17 September 2010; revised 21 March 2011; accepted 28 March 2011 